\title{
The Seroprevalence of Hepatitis B Virus Among Children Attending Urban and Rural Hospitals
}

\author{
MOHD. SHAMSUL ALAM ${ }^{1}$, SOOFIA KHATOON ${ }^{2}$, REZOANA RIMA ${ }^{3}$, SABINAAFRIN $^{4}$
}

\begin{abstract}
Objectives: This study was conducted to a) find out and compare the period prevalence of HBsAg in children attending outdoor and indoor of an urban and a rural hospital b) determine the risk factors for Hepatitis B surface antigen positivity.

Materials and Methods: Three hundred and twenty three children were included in this study. Among them 162 attended an urban hospital and 161 attended a rural hospital. Collected sera were examined for HBsAg by ELISA method in a standard laboratory.

Results: Among the 162 urban children 17 (10.5\%) were found to be HBsAg positive and among the 161 rural children 6 (3.7\%) were found to be HBsAg positive. This difference is statistically significant $(P$ value $<0.05)$.

In urban area, 12 (16.2\%) school aged, 3 (6\%) pre-school children and 2 (5.5\%) infants were found to be HBsAg positive. In rural area, more pre-school (6\%) than school children (2.8\%) were found to be HBsAg positive. In urban area, $11.5 \%$ male children and $9.5 \%$ female children were found to be HBsAg positive and in rural area, 5.2\% male and $2.8 \%$ female children were to be HBsAg positive. Among $17 \mathrm{HBs}$ Ag positive cases who attended urban hospital, 11 (19.6\%) had past history of jaundice and 6 (5.6\%) had no past history of Jaundice ( $P$ value $<0.05)$. Among those $17 \mathrm{HBs}$ Ag positive cases, 13 (14.6\%) had past history of inoculation within last 6 months and 4 (5.5\%) had no such history. This difference is also statistically significant ( $P$ value $<0.005)$.

Conclusion: Prevalence of positive HBsAg marker is fairly high in urban children (10.5\%). Prevalence of HBsAg has no age and sex prediction. More sero-positive children in urban area have previous history of jaundice and history of inoculation in last 6 months, but no one in rural area had history of jaundice or inoculation within last 6 months.
\end{abstract}

Key word: Serosurvilance, Hepatitis B virus.

N.B. This publication is based on a dissertation

\section{Introduction}

Hepatitis B virus (HBV) infection is a major public health problem globally. It may lead to chronic liver diseases and primary liver cancer, often resulting from chronic carriage of the virus ${ }^{1}$. Though identification of Hepatitis $B$ virus is the result of recent advancement, it was Hippocrates who described Hepatitis as an infectious disease more than 2000 years $\mathrm{ago}^{2}$. Hepatitis B is endemic throughout the world especially in tropical and developing countries and also in some regions of Europe. Its prevalence varies from country to country and depends upon complex mix of behavior,

1. Medical Officer, Narayanganj 250 bed Hospital

2. Professor and Head of the Department of Paediatrics, Institute of Child and Mother Health (ICMH)

3. Specialist Paediatrician, United Hospitals Ltd

4. M phil Student, NIPSOM

Correspondence : Dr. Mohd. Shamsul Alam environmental and host factors ${ }^{3}$. Five percent of the world population is estimated carriers and more than two million people die from Hepatitis B infection every year ${ }^{4}$. One in five and one in twenty carriers die prematurely from liver cirrhosis and liver cancer, respectively ${ }^{5}$. Children infected perinatally, during first four years of life and latter on, have a $70-90 \%, 30 \%$ and $10 \%$ chance of becoming carriers respectively ${ }^{5}$. The magnitude of HBV infection among Bangladeshi children is unclear. A few studies are carried out in this age group. Previous reports documented an intermediate level of endemicity with adult carrier rates varying from 5.5 to 23 percent of the population ${ }^{6-8}$. This study is an effort to determine the prevalence and risk factors for of Hepatitis B surface antigen positivity among the children of 0-15 year age attending an urban and a rural hospital. 


\section{Materials and Methods}

This descriptive cross sectional study was carried out among the children attending in outdoor and indoor of Department of Paediatrics of Sir Saliniullah Medical College and Mitford Hospital and Mirzapur Upazilla health complex, Tangail, for a period of 6 months from $1^{\text {st }}$ November 2002 to $30^{\text {th }}$ April 2003. Children of age 0-15 years were included in the study. Children who were very sick with bleeding disorder were excluded from the study.

The sample was estimated by the following formula $\mathrm{N}=\mathrm{Z}^{2} \mathrm{pq} / \mathrm{d}^{2}=323\{\mathrm{Z}=1.96$ (95\% confidence limit), $p=15 \%$ (estimated prevalence), $d=0.05 \%$ (5\% error), $\left.\mathrm{q}=\mathrm{p}^{-1}\right\}$. Non-probability purposive sampling technique was followed. Systematically every third child was included in the study.

Total 323 children were included, 162 of them from urban and 161 from rural areas. The researcher himself performed face-to-face interview to collect necessary information.

Blood samples from the children were collected with prior permission from the parents. Serum was separated on the spot (SSMCH or THC) by centrifuging (to prevent hazard of haemolysis during transfer to diagnostic laboratory). Serum sample was then tested for HBsAg employing ELISA (Enzyme Linked Immunosorbent Assay) method in a diagnostic center in Dhaka, after standardization as per the requirement of the study.

After checking completeness and correctness, all collected data were entered and analyzed using a personal computer. Data was analyzed on the basis of individual variable and comparing between different variables. According to the objectives different tables were prepared and analysis was done by SPSS program.

\section{Results}

Present study involved 323 children (162 attending an urban hospital and 161 a rural hospital). Among them 17 (10.5\%) urban children and 6 (3.7\%) rural children were found to be HBsAg positive. The difference was statistically significant $(P$ value $<0.05)$ (Table I). Majority of participants were in school age group (515 years) in both urban (45.6\%) and rural (66.4\%) settings (Table II). Sero-prevalence was more in school children of urban area (16.2\%) than rural area (2.8\%) (Table II). More male children in rural area (5.2\%) were HBsAg positive than female (2.8\%) (Table III), whereas in urban area there was no sex predilection. Among the 17 (10.4\%) HBsAg positive cases who attended urban hospital 11 (19.6\%) had past history of jaundice (Table IV) which is statistically significant. But 6 (3.7\%) HBsAg positive cases in rural hospital had no past history of jaundice.

Among the 17 (10.5\%) HBsAg positive cases in urban hospital, 13 (14.6\%) had past history of inoculation within last 6 months and 4 (5.5\%) had no such history (Table $\mathrm{V}$ ). This is statistically significant ( $\mathrm{P}$ value $<$ 0.005). Forty (28.8\%) children among 161 at rural hospital had history of inoculation within last 6 months but all were negative for HBsAg and 6 (3.7\%) were positive for HBsAg but there was no history of inoculation in them (Table $\mathrm{VI})$. So, there is no relation between positive seroprevalence of HBsAg and history of Inoculation in rural area.

Table - I

Number and percentage of children by serological marker of hepatitis $B$ virus in urban and rural hospital $(N=323)$

\begin{tabular}{lccc}
\hline Serological marker(HBsAG) & Urban hospital No (\%) & Rural hospital No. (\%) & Total No. (\%) \\
\hline Positive & $17(10.5)$ & $6(3.7)$ & $23(6.8)$ \\
Negative & $145(89.5)$ & $155(96.2)$ & $300(93.2)$ \\
\hline Total & $162(100)$ & $161(100)$ & $323(100)$ \\
\hline
\end{tabular}

$P$ value $<0.05$ 
Table-II

Number and percentage of HBsAg positive cases attending urban and rural hospitals by age $(N=323)$

\begin{tabular}{|c|c|c|c|c|}
\hline \multirow[t]{2}{*}{ Age (years) } & \multicolumn{2}{|c|}{ Urban hospital } & \multicolumn{2}{|c|}{ Rural hospital } \\
\hline & $\begin{array}{c}\text { Participants } \\
\text { No. }(\%)\end{array}$ & $\begin{array}{c}\text { HBsAg positive cases } \\
\text { No. (\%) }\end{array}$ & $\begin{array}{c}\text { Participants } \\
\text { No. (\%) }\end{array}$ & $\begin{array}{c}\text { HBsAg positive cases } \\
\text { No. (\%) }\end{array}$ \\
\hline $0-1$ & $38(23.4)$ & $2(5.5)$ & $0(0)$ & $0(0)$ \\
\hline $2-4$ & $50(30.8)$ & $3(6)$ & $54(33.5)$ & $3(6)$ \\
\hline $5-15$ & $74(45.6)$ & $12(16.2)$ & $107(66.4)$ & $3(2.8)$ \\
\hline Total & $162(100)$ & $17(10.4)$ & $161(100)$ & $6(3.7)$ \\
\hline
\end{tabular}

Table-III

Number and percentage of HBsAg positive cases attending urban and rural hospitals by sex $(\mathrm{N}=323)$

\begin{tabular}{lccccc}
\hline Sex & \multicolumn{2}{c}{ Urban hospital } & & \multicolumn{2}{c}{ Rural hospital } \\
\cline { 2 - 3 } & Participants & HBsAg positive cases & & Participants & HBsAg positive cases \\
& No. (\%) & No. (\%) & & No. (\%) & No. (\%) \\
\hline Male & $78(48.2)$ & $9(11.5)$ & & $57(35.4)$ & $3(5.2)$ \\
Female & $84(51.8)$ & $8(9.5)$ & & $104(64.6)$ & $3(2.8)$ \\
\hline Total & $162(100)$ & $17(10.4)$ & $161(100)$ & $6(3.4)$ \\
\hline
\end{tabular}

Table-IV

Number and percentage of HBsAg positive and negative cases attending urban hospital by past history of jaundice

\begin{tabular}{lccc}
\hline Previous H/O Jaundice & Participants & HBsAg Positive cases & HBsAg Negativecases \\
& No. (\%) & No. (\%) & No. (\%) \\
\hline Yes & $56(34.6)$ & $11(19.6)$ & $45(80.3)$ \\
No & $106(65.4)$ & $6(5.6)$ & $100(94.3)$ \\
\hline Total & $162(100)$ & $17(10.4)$ & $145(89.5)$ \\
\hline
\end{tabular}

$P$ value $<0.05$

Table-V

Number and percentage of HBsAg positive and negative cases attending urban hospital by history of inoculation in last six month

\begin{tabular}{lccc}
\hline $\begin{array}{l}\text { History of inoculation } \\
\text { in last } 6 \text { months }\end{array}$ & $\begin{array}{c}\text { Participants } \\
\text { No. }(\%)\end{array}$ & HBsAg Positive cases & HBsAg Negative cases \\
\hline Yes & $89(54.9)$ & $13(14.6)$ & No. (\%) \\
No & $73(45.1)$ & $4(5.5)$ & $76(85.4)$ \\
\hline Total & $162(100)$ & $17(10.5)$ & $69(94.5)$ \\
\hline P value $<0.005$ & & & $145(89.5)$ \\
\hline
\end{tabular}


Table-VI

Number and percentage of HBsAg positive and negative cases attending rural hospital by history of inoculation in last six month

\begin{tabular}{lccc}
\hline History of inoculation & Participants & HBsAg Positive cases & HBsAg Negative cases \\
in last 6 months & No. (\%) & No. (\%) & No. (\%) \\
\hline Yes & $40(24.8)$ & $0(0)$ & $40(100)$ \\
No & $121(75.1)$ & $6(4.9)$ & $115(95.0)$ \\
\hline Total & $161(100)$ & $6(3.7)$ & $155(96.3)$ \\
\hline
\end{tabular}

\section{Discussion}

Hepatitis $B$ is a global problem with moderate prevalence in Bangladesh 6 . It is the commonest cause of primary hepatocellular carcinoma in the world? Asymptomatic carriers are the most common source of infection to others. HBV is a self-limiting disease in 90-95\% cases. In children $5-10 \%$ cases become chronic carriers ${ }^{5}$. Chronic carriers are detected by the presence of HBsAg marker. There are few studies done previously on this topic among children in our country. In this study, it was found that seroprevalence of HBsAg was $10.5 \%$ in urban area and $4 \%$ in rural area. This may be due to density of population and unhygienic living style in urban area. A hospital based study carried out by MN Islam et al in 1984 in Dhaka Medical College on 576 apparently healthy male showed $7.8 \%$ HBsAg positive cases ${ }^{9}$. The result of present study is a bit higher (10.5\%) in urban hospital. Prevalence of Hepatitis B in Viqarunnisa Noon School children in Dhaka was found $2.3 \%$ by Laskar $\mathrm{MS}^{10}$. The result is lower than the present study- probably due to high socio-econoinic status in those subject. A cross sectional study by $M$ Rahman et al in a village of Rangpur district found that overall sero prevalence of HBsAg was $6.4 \%^{11}$. The result of present study $(3.7 \%)$ is little bit lower to that study. Overall seropositivity rate of HBsAg was found in a study by Murheker et al among Nicoberes was $23.3 \%^{12}$. This finding is higher than the present study because Hepatitis B infection is hyper-endemic among the primitive tribes of Andaman and Nicober islands. It is revealed from this study that in urban area and also in rural area no specific age group was more affected. In his study Murheker et al has also found no relation between age and sero-prevalence of $\mathrm{HbsAg}^{12}$. This is also supported by M Rahman ${ }^{11}$. In this study it was also found that there was no relation of sero-prevalence with any age group. This is also found by Fakir $\mathrm{A} \mathrm{H}$ that age and sex had relationship with HBsAg positivity ${ }^{13}$. Present study showed that $19.6 \%$ positive cases had previous history of jaundice. Chowdhuri SGM et al showed in their study that $12.9 \%$ individuals had previous history of jaundice ${ }^{14}$. In rural area no HbsAg positive child had previous history of jaundice. However, this study discover a fact that among the HbsAg positive urban children significant number (14.6\%) had a past history of inoculation within last six months. This finding is also supported by Hutin $Y S$ et al that injections were the source of acute hepatitis $B$ infection among adults and children ${ }^{15}$. This piece of information is very important for planning prevention of Hepatitis B infection.

\section{Conclusion and Recommendation}

The sample size of the present study is not representative of whole population of a densely populated country like Bangladesh. However, it reveals from the study that prevalence of HBsAg marker is fairly high in urban children (10.5\%). More seropositive children in urban area had previous history of jaundice and history of inoculation, unlike rural situation. Inoculation could be an etiology in urban area. So, use of disposable syringe and needle should be reinforced to prevent Hepatitis $B$ infection.

\section{References}

1. Francisco A, Hall A, Alam N, Hawkes S, Azim T. Hepatitis B infection in Bangladeshi mothers and infants. Southeast Asian J trop Med Public Health 1999; 30: 296-8.

2. Vogton. Viral Hepatitis - The Past, The Present and The Future. AMJ; 1980; 2: 1-5.

3. Park K. Infectious Disease in Text Book of Preventive and Social Medicine, $14^{\text {th }}$ edition, Banarsidas Bhanot Publication India: 1985. 445447.

4. Zaman S, Khan M, Alain K, Williams R. Primary Hepato-cellular and Viral Hepatitis B and C 
infection in Bangladeshi Subjects. Journal Gastroenterology and Hepatology 2004; 19: 41930.

5. Edmunfs WJ, Medley GF, Nokes AJ, Whittle HC. Influence of age on the development of the hepatitis B carrier state. Proc R Soc Lonf B 1994; 253: 197-201.

6. Salam MN. Viral Hepatitis - Past and Present. Hepatitis B Virus Infection at Dhaka. Bangladesh Med Res Council Bull 1984; 13: 16-26.

7. Mustafa M, Islam MN. Hepatitis B Virus Markers among the Prostitutes of Dhaka. Bangladesh Med Res Council Bull 1986; 22: 98-11.

8. Satter H, Islam MN. Hepatitis B virus markers among the prostitutes of Dhaka, Bangladesh. Med Res Council Bull 1996; 15: 67-71.

9. Islam MN. Hepatitis B infection in Dhaka, Bangladesh. Bangladesh Med Res Council Bull 1984; 10: 1-6.
10. Lasker MS, Harada N, Khan F. Prevalence of Hepatitis of Hepatitis B surface antigen ( $\mathrm{HbsAg}$ ) in Vikarunnessa. Cent Eur J Public Health 1997; 5: 202-04.

11. Rahman M, Amanullah M, Sattar H. Seroepiderniological study of Hepatitis B virus infection in a village. Bangladesh Med Res Council Bull 1997; 23: 38-41.

12. Murheker MV, Zotdpey SP. Hepatitis B infection among Indian tribe: Need of vaccination programme. Indian J Med Res 2000; 111: 199-203.

13. Fakir AH. Factors influencing the hepatitis $B$ virus transmission in local population. M Sc Thesis University of Dhaka. 1992.

14. Chowdhury SGM, Ahmed Q, Islam MN. HbsAg in unscreened operated patients. Bangladesh Medical Research Council Bull 1991; 17: 11-16.

15. Hutin YJ, Harpaz R, Drobeniuc K, Melinic A, Ray $C$. Injection given in health care setting as a major source of hepatitis B in Molodova. International Journal of Epidemiology 1999; 61: 206-09. 